\title{
Translating Culture-specific Items in Vietnamese Cultural Festival Texts into English
}

\author{
Nguyen Thi Nhu Ngoc ${ }^{1 *}$, Van Thi Nha Truc ${ }^{1}$, Nguyen Anh Quan ${ }^{1}$, Le Thi Ngoc \\ Anh $^{1}$, Tran Cao Boi Ngoc ${ }^{1}$ \\ ${ }^{1}$ University of Social Sciences \& Humanities, Viet Nam National University, Ho Chi Minh City, Viet Nam \\ *Corresponding author. Email:nhungoc@hcmussh.edu.vn
}

\begin{abstract}
In recent years, tours of cultural festivals in Viet Nam have been on the rise thanks to the increasing demands from foreign visitors, which requires high-quality English versions of cultural festival texts for tour guidance and tourism promotion, contributing to a positive image for Viet Nam. However, such texts are burdened with a large number of culture-specific items that are not easily translated from Vietnamese into English. This paper aims at exploring culture-specific terms in cultural festival texts, identifying their categories, and then applying appropriate techniques to translate them from Vietnamese into English. Using the SLD MultiTerm software, the researchers collected the data from 300 texts about the 100 most popular festivals organized throughout Viet Nam all year round. The research results are a list of Vietnamese-English culture-specific terms with interpretations of their meanings and translations, and they all serve as a useful resource for tourism, culture, and translation courses at universities in Viet Nam.
\end{abstract}

Keywords: Cultural Festival, Culture-Specific Item, Translation, Tourism, Text

\section{INTRODUCTION}

Since the 2010s, spiritual tourism has favorably developed in Viet Nam. Accompanied with it are tours of cultural festivals in many localities thanks to their cultural and historical values. Cultural festivals are considered ideal tourist destinations and environments for the development of spiritual tourism. Viet Nam is proud to be a nation with numerous cultural festivals taking place all year round throughout its territory. There exist about 8,000 festivals, and half of them can be exploited for spiritual tourism [1]. Thus, the research on local and national cultural festivals is of great importance for international visitors to Viet Nam in the current wave of globalization.

When skimming any travel agency's tours, we can easily find out at least one or two tours of spiritual tourism, which indicates that the demand for communication in English in this field is quite essential. There should be serious research on bilingual Vietnamese-English texts of cultural festivals for tourist websites and tour guides, contributing to promoting knowledge as well as enhancing the image of Viet Nam's tourism in the eyes of international tourist communities.

Accordingly, the demand for tourism in English has 
been on the increase to serve a wide range of lecturers and students in tourism-related programs at many universities in Viet Nam. Several textbooks by popular publishers worldwide can be used as a learning or reference materials in their curricula, such as Tourism, Hospitality, Travel Management, Tourism Geography, and English Language. They all provide useful knowledge in terms of tourism language. However, practice-based entirely on such tourism textbooks is not enough to enable most students to perform their tasks effectively and professionally in the field of tourism, especially tourism regarding specific cultural festivals in Viet Nam. They need to be well-equipped with additional knowledge related to Viet Nam's tourism and its specific characteristics besides the general knowledge of world tourism.

Therefore, more research on tourism language and translation from Vietnamese into English is crucial. This paper aims at exploring culture-specific items (CSIs) in informative texts about Vietnamese cultural festivals and their equivalents in English. The study is conducted under the guidance of two research questions: "What are common culture-specific items in texts about Vietnamese cultural festivals?" and "How to translate these culture-specific items from Vietnamese into English?"

\section{LITERATURE REVIEW}

\subsection{Cultural festivals}

A festival is defined as "an event, a social phenomenon, encountered in virtually all human cultures" [2, p.1]. It is also a form of cultural event that highlights the unique features of a tourist attraction or theme [3]. Respectively, Oxford's Online Lexico [4] describes a cultural festival as one "featuring arts and events specific to a particular culture, especially one celebrating and promoting that culture in a wider public context."
These definitions help confirm that festivals in tourism are quite an important part. It is because visitors and travelers would pay much attention to the colorful variety and dramatic intensity of a festivals' dynamic choreographic and aesthetic aspects, valuing deep meanings underlying its historical roots and the involvement of its natives [2].

\subsection{Cultural festivals in Viet Nam's spiritual tourism}

In the proceedings of the First UNWTO International Conference on Spiritual Tourism for Sustainable Development in Viet Nam [5, pp.20, 116], the experts agreed that Vietnamese cultural festivals play a significant role in its spiritual tourism: "Viet Nam has a great potential to develop in terms of spiritual tourism because of its traditional culture, religions, and beliefs. It can be seen through the diversity and quantity of religious relics and a large number of different religions and traditional festivals organized during a year." (Nguyen Văn Tuấn, Chairman, Viet Nam National Administration of Tourism); "For international tourists, spiritual tourism relates more to cultural exchange, learning and understanding. This can be manifested in attending a traditional cultural performance." (Kai Partale, Tourism Specialist, ESRTEnvironmentally and Socially Responsible Tourism in Viet Nam)

Many studies show that Viet Nam's spiritual tourism has a distinct seasonality, and the peak season is the time for big festivals to be held in spiritual and cultural spaces. In this country, every faith or religion has its own festivals throughout the year, and the time for organizing these festivals is also the high season for spiritual tourism [6].

On its website, Viet Nam National Administration of Tourism views festivals as "a living museum for original cultural features of the nation that have been handed over and inherited through centuries" [7]. 
Accordingly, a common procedure of a Vietnamese cultural festival consists of three steps: (1) Preparation - the organizers prepare activities after the completion of a festival season and before the organization of a new festival, i.e., preparations for the next festival season are carried out right after the previous one ends; (2) Festival participation - various activities pertaining to the two main sections, i.e., the ceremony (LẼ) (sacred rituals, processions, incense offerings) and the entertainment (HộI) (games, competitions), take place to express great cultural values of the festival and attract its participants; and (3) Festival closing (farewell to the participants, farewell to the festival) - the organizing committee performs a thanksgiving ceremony and closes the monument/space where the festival takes place.

As can be seen, similar to those worldwide, Vietnamese cultural festivals are socio-cultural products derived from ancient times. Cultural festivals are spaces where people find joy and spiritual relief as well as learning about traditional values, which contributes to social development.

\subsection{Language features of cultural festival texts in Vietnamese}

As specified in the Viet Nam Tourism Occupational Skills Standards (VTOS) [8, p.14], one of the main tasks of tour narrators and heritage speakers at important historical and religious sites in Viet Nam is to present adequate information about the history of formation and development of these places to visitors so that they can fully understand cultural, environmental or heritage values. It is also recommended that the tour narrators/speakers create an awareness of the values of local traditions, cultural heritages, and tourist attractions. This means that texts used or compiled by tour narrators/speakers should meet certain standards so that they can transfer the values of a tourist site to the best possible extent. In terms of structure, a typical text about a cultural or traditional festival in Viet Nam suggested by Viet Nam's Ministry of Education and Training [9] should consist of three sections: (1) Opening - providing an overview of the festival; (2) Contents - providing its features based on the temporal structure combined with the logical structure with essential details about its organizing time, location, origin, preparation, activities and so on; and (3) Closing - stating the meaning or values of the festival.

In addition, the VTOS [ 9, p.24] highlights that an important factor in designing a tourist presentation is its specific topic focusing on the needs of its audiences; the structure and content should be arranged in an attractive and engaging flow to maintain their interest and to provide accurate information above all.

In general, an informative text about a cultural festival should provide information (on cultural spaces, values, religious and entertaining activities, and incomparable customs and traditions during its process) that interests its listeners. As a result, in such a text, using lots of words and phrases to deliver information about cultural values and festive activities is a must. Particularly, in the two main sections of a cultural festival, i.e., the ceremony and the entertainment, there are important and indispensable activities which may entail many unique details now and then found in the number of cultural festivals. They would be expressed in terms or specific phrases that are called culture-specific items (a term used in translation and further explained in the next subsection). These CSIs are certainly a challenge in translation from Vietnamese into English.

\subsection{Translation of culture-specific items}

\subsubsection{Translation}

Translation is not a simple process. Its nature is the transformation of a source text in one language into another without changing the content in the source 
text; in fact, the translation process is transcoding the information from language $\mathrm{A}$ to language $\mathrm{B}$ or vice versa [10, p.4]. Some definitions of translation widely used in the world are: Translation is "replacing a text in one language with an equivalent text in another language" [11, p.20]; Translation is "reproducing in the receptor language the closest natural equivalent of the source language message, first in terms of meaning and secondly in terms of style" [12, p.12]. Translation is "transferring the meaning of the source language into the receptor language". i.e., a process is done without changing the idea or meaning of the source language" [13, p.3]; Translation is "rendering the meaning of a text into another language in the way that the author intended the text" $[14, p .5]$.

It is obvious that the concept of translation is viewed with two approaches: (1) Translation is a process whose product is to achieve the best equivalence in the meaning of the source text $[11,13]$; (2) Translation is a process whose product is to achieve the best equivalence in the content of the author's message in the source text $[12,14]$. In this paper, common culturespecific items are found in cultural festival texts which are presented in written or spoken forms to deliver values of cultural traditions, cultural heritage, and local attractions. Hence, the second approach is more appropriate. That means translation is a process whose final product is a target text that represents the author's informative purpose in the source text to its listeners or viewers being foreign visitors to Viet Nam. English equivalents of Vietnamese culture-specific items in this text are the results of an entire process of analyzing and delving into the messages in Vietnamese so that the translator can compare, contrast, and then find out the most appropriate equivalents in English.

\subsubsection{Classification of culture-specific items in texts about cultural festivals}

In translation of texts about Vietnamese cultural festivals, besides several common words and phrases that are popular in many other fields, a translator certainly finds items expressing cultural objects and concepts related to a particular value or culture. They are the so-called culture-specific items, a terminology first used by Aixelá [15, p.58]. In his study, a CSI is an item "whose function and connotations in a source text involve a translation problem in their transference to a target text, whenever this problem is a product of the non-existence of the referred item or of its different intertextual status in the cultural system of the readers of the target text." This definition is relevant to terms in Vietnamese texts about cultural festivals whose connotations are closely associated with some cultural or historical contexts that only exist in some Vietnamese cultural festivals, and then it is not easy to perceive their direct equivalents in English.

Currently, there are several taxonomies of CSIs; and three widely used are as follows:

(1) Vlahov \& Florin [16] group CSIs into five categories: (1) geographical (geographic formations, man-made geographical objects, flora, and fauna that are all considered distinctive to a cultural space); (2) ethnographic (food and drink, clothing, places of living, furniture, pots, vehicles, names of occupations and tools); (3) art and culture (music and dance, musical instruments, feasts, games, rituals, and their characters); (4) ethnic (names of people, nicknames); and (5) socio-political (administrative-territorial units, offices, and representatives, ranks, military realia).

(2) Newmark [14] places CSIs into five categories: (1) ecology (flora, fauna, hills, winds, plains); (2) material culture (food, clothes, houses and towns, transport; (3) social culture (work and leisure); (4) organizations, customs, and ideas (activities, procedures, concepts attached to politics and 
administration, religion, arts); and (5) gestures and habits.

(3) Gudavičius, as cited in Blažytė \& Liubinienè [17], considers CSIs as non-equivalent in other languages because different cultures may have different things or concepts, and these nonequivalent lexical items are of great importance in the cognition of the material and spiritual culture; therefore, he classifies them into two groups: (1) material items; and (2) spiritual items.

The first taxonomy is quite comprehensive and easy to group words into a specific category, saving translators time on locating vocabulary, recognizing related elements, and finding equivalents with clear directions. The second shares some similarities with the first one and is quite accessible for translators, and the third is brief yet highly general and requires the translator's deep understanding in order to find appropriate translation equivalents. In a comparison of the three ways of categorization, we observe that the first taxonomy shares similarities in Vietnamese cognition and culture. Thus, this taxonomy is the best choice for our research.

\subsubsection{Some challenges in the translation of culture-specific items}

\subsubsection{Translatability and untranslatability}

Several researchers have different views on the translatability of specific terms from a language to another. In Pym et al. [18, p.273], translatability can be understood as the "capacity for some kind of meaning to be transferred from one language to another without undergoing radical change." Meanwhile, Friedrich [19, p.11] affirms that translators have to deal with "the reality of untranslatability from one language to another."

Additionally, the differences between cultures are often the main cause of translation problems and help differentiate between linguistic and cultural untranslatability. Linguistic differences between the source text and target text lead to untranslatability when there is no lexical or syntactical substitute in the target language for a source language term. Whereas cultural untranslatability is due to the absence in the target language culture of a relevant situational feature for the source text. As a result, linguistic untranslatability is more "absolute" than cultural untranslatability, which is a product of unusual rendering in the target language [11].

In reality, when translating lexical items from a source text to a target one, the translator can easily find translation equivalents for those common in many areas and, at the same time, decide to have some vital transformation or adaptation to fully convey the message from CSIs in the source text. Translators need to be aware, however, that not all linguistic differences pose the same challenges and that translatability depends on many other factors. Hermans [20, p.302] argues that the untranslatability is reflected in the relative form in terms of aspect, kind, and degree. Accordingly, the translator needs to have a thorough analysis to minimize this untranslatability.

As can be seen, in the case of culture-specific items, there always exists a "blurred boundary" between translatability and untranslatability, and the translator is the one to break this line with a good choice of translation strategies.

\subsubsection{Culture-specific items and their equivalents in a target language}

Baker [21] attests that a word in the source language can express a concept unknown in the target language's culture. It may refer to an abstract/concrete concept, a religious belief, a social custom, or even a 
food item. In our research on cultural festival texts, such words are very common.

To explain possible reasons for the phenomenon of non-equivalence, Terestyényi [22, p. 14] states that CSIs depend much on their context because once a textual element in a text is a culture-specific item with a connotative meaning in the source culture, it can only be understood based on the relation between the two languages.

In respect to possible equivalents, Terestyényi [22, p.14], based on the view that a word has a meaning with different components and its meaning is closely tied to the referential meaning and its relationship with those of others in the vocabulary system of a given language, states that this word possesses different emotional and associative meanings and extralinguistic knowledge and that it is impossible to have absolute equivalence between words in two languages. However, based on referential equivalence, we can get absolute equivalence because the fact that the words of two languages may refer to the same reality and the segmentation of reality can be similar to some extent. Also, due to the different segmentation, the meanings of these two words are not always the same, and then we may find working and partial equivalents. Each nation in the world has its own society, material, and intellectual culture; therefore, there are some elements impossible to be observed in another nation. As a result, there are some items whose donative meanings do not exist in another culture; some items that can be found but do not have any lexicalized forms because they may be significant in one culture but might not be in another; and even some elements which might be comparable to each other, but due to the different concept systems they are not equivalents at all.

Vietnamese culture and western cultures originate from different social institutions with different concept systems. Thus, the translator needs to have some comparison and contrast in order to find the most suitable translation equivalent in a particular context.

\subsubsection{Translation of culture-specific items}

In terms of procedure, Baker [21] proposes different translation techniques for CSIs at the word level, including translating with a more general word, translating with a more neutral/less associative wording, translating with interpretation, and using relevant words. In terms of strategy, he emphasizes the need for appropriate translation strategies, including translating with cultural substitution, in which a CSI in the source culture is replaced with another in the target culture whose propositional meaning is somehow different but has the same effect on the reader/listener of the target text; translating with a loan word or loan word accompanied with further explanation, in which a loan word is used or a loan word is supported with an explanation, and once explained, the loan word can be accepted.

Kwieciński [23] proposes three methods to translate CSIs, including (1) Exoticisation, a group of strategies for transferring CSIs in the target text with "foreignisation." This strategy group is supported because it gives the translation a "local color" [14, p. 82]; (2) Explanation, a group of strategies for using extratextual gloss related to the semantics or implications of CSIs. According to Aixelá $[15$, p. 62), it helps to provide equivalents acceptable to the reader/listener in the target text; and Schäffner and Wiesemann [24, p. 34] agree that explanatory strategies convey a better understanding of CSIs in the target text; (3) Assimilation, a group of strategies CSIs that are replaced by those in the target culture, where the text is rewritten to suit the target cultural context for a particular need of information. Aixelá [15] affirms that these strategies help the reader/listener better understand CSIs thanks to the new version in the 
target language. This version is recognized to originate from the source cultural system.

Obviously, the translation methods for CSIs by Baker and Kwieciński [21, 23] are similar to some extent. However, the detailed taxonomy by Kwieciński helps the translator to make flexible choices for equivalents of CSIs in tourism texts, especially those about cultural festivals where cultural values are presented in various ways. Therefore, in this study, we apply his taxonomy with specific translation strategies and techniques as described above.

\subsection{Previous studies}

In the world, a number of studies on tourist vocabulary and translation have been carried out: Dastjerdi \& Abdolmaleki [25] evaluated the quality of translations from Peruvian to English to find common translation errors in travel guidebooks; Skibitska [26] analyzed the main features of tourism-related texts on travel websites to identify the criteria for translation assessment in terms of pragmatics, communication, and stylistics; Yifeng \& Fang [27] conducted a survey on Chinese-English bilingual corpus concerning lexical characteristics; Bagheridoust \& Mahabad [28] examined architectural texts with lots of CSIs and focused on the most frequently used strategies by writers/translators based on Van Doorslaer's Model.

In Viet Nam, there have been few types of research on the issue of Vietnamese-English bilingualism in tourism: Hà [29] collected English-Vietnamese tourism terms from dictionaries to clarify the structural features and made a proposal on standardizing Vietnamese tourist terminologies; Tam et al. [30] analyzed Vietnamese-English signs at tourist sites and found a number of problems in spelling, grammar, word use, semantics, and pragmatics.

As can be seen, the picture of the language research on Viet Nam's tourism has remained several open questions. We have found almost no work on common
CSIs found in texts about cultural festivals and their translation. Therefore, this research is hoped to shorten this gap, serving as a useful reference source for further relevant research.

\section{METHODOLOGY}

\subsection{Research setting and sampling}

Within the scale of this paper, the research focused on identifying CSIs in the form of noun phrases. The criteria for identification were that this nominal CSIs consist of at least one main noun that owns a specific meaning to express some specific information in these texts. In detail, they are used to refer to things, phenomena, realities, or concepts related to cultural traditions, etc. Their denotative and/or connotative meanings belong to the five groups as categorized by Vlahov \& Florin [16]. In addition, they are found in texts about Vietnamese cultural festivals, which were collected mainly from secondary data sources, including texts in Vietnamese from tourist magazines, monographs, travel guides, websites that are relevant to spiritual tourism, and tourist promotion brochures.

\subsection{Research design}

This is mixed-method research where the data were collected from archival documents using both quantitative (statistical and classification) and qualitative (library method) approaches. Both approaches were employed to identify CSIs in the collected texts. Also, the descriptive, comparative, and contrastive methods were utilized so that the Vietnamese CSIs could be translated with appropriate equivalents in English.

\subsection{Data collection and analysis}

Texts about cultural festivals for the research data collection were from reliable sources of reference, including officially published monographs, travel manuals, websites belonging to the Departments of culture, sports and tourism of provinces and cities 
across Viet Nam, and websites of big tourist companies in Viet Nam, which legally operate with stable numbers of international tourists, providing tourism services, and being recognized by world tourism organizations.

Secondary resources also came from tourist documents in the forms of bilingual tourist catalogs, books, leaflets, and travel dictionaries so that the researchers can make full use of reference and comparison to decide the best translation equivalents for the collected CSIs.

Among the 8,000 large- and small-scale cultural festivals in all three regions in Viet Nam, we selected just 100 exemplary or representative festivals in three regions, including 40 festivals in the North, 30 in the Central, and 30 in the South. The selection was based on the list of festivals recognized as intangible cultural heritage and/or human heritage in Viet Nam [31, pp. 44-49]. However, due to the explosion of information on the Internet, it is likely to find numerous texts presenting Vietnamese cultural festivals. Thus, information sources need to be carefully checked and filtered for high accuracy. Thus, for each of the selected festivals, we collected three relevant texts, including text 1 from a monograph; text 2 from the website of the Department of Culture, Sports and Tourism of the province/city where the festival takes place; and text 3 from a travel agency/company which legally operates with stable numbers of international tourists and/or is acknowledged in the world tourism. Thus, the information about the 100 festivals was analyzed with a multidimensional and accurate view.
After a monolingual corpus in Vietnamese was built from the total 300 collected texts about 100 cultural festivals in Viet Nam, we used the SLD MultiTerm Software [32] (which is also a computer-aided translation tool used for the professional translation environment) to process the monolingual texts and extract the word and word phrases into a list of CSIs from this corpus. To do this, we manually extracted terms from the source texts in the corpus and selected common noun and verb phrases with high frequencies in the form of one to four-word phrases. Then all the members in the research group discussed several times to group them into one of the five categories of CSIs as described in Section 2. For each CSI, we selected more or less 10 sentences in which the term was used so that we could better understand its meaning and language context as well as make a good decision on its English equivalent.

\section{FINDINGS AND DISCUSSIONS}

\subsection{Common culture-specific items in texts about Vietnamese cultural festivals}

Table 1 shows the number of common CSIs from the corpus of 300 texts about 100 Vietnamese cultural festivals. The total number of CSIs was 611. Of the five categories, those in the art and culture recorded the highest amount with 349 items, accounting for $57.2 \%$; the socio-political ones took the secondhighest percentage of $15.5 \%$ with 95 items. As for the other three, namely geographical, ethnographic, and ethnic, they varied from 7.5 to $10 \%$, respectively.

Table 1. Categories of CSIs in Vietnamese cultural festival texts

\begin{tabular}{|l|c|c|}
\hline Category & Number & Percentage \\
\hline geographical & 46 & 7.5 \\
\hline ethnographic & 60 & 9.8 \\
\hline art and culture & 349 & 57.2 \\
\hline ethnic & 61 & 10 \\
\hline
\end{tabular}




\begin{tabular}{|r|c|c|}
\hline socio-political & 95 & 15.5 \\
\hline Total & 611 & 100 \\
\hline
\end{tabular}

The statistical numbers imply that we would face lots of challenges in translating lexical items about art and culture in the collected data. It proves to be true because each of the cultural festivals has its distinctive music and dance, musical instruments, feasts, games, rituals, and so on. In addition, it was not easy to deal with 95 CSIs associated with socio-political values (i.e., administrative-territorial units, offices and representatives, ranks, military realia) and find their absolute equivalents for CSIs because the social system and political institution in Viet Nam are quite different from those in western countries, and the translation task could even become more demanding in regard to the cultural festivals rooted in the period

Table 2. Equivalents for CSIs in texts about cultural festivals from Vietnamese into English

\begin{tabular}{|c|c|c|c|c|c|}
\hline \multicolumn{3}{|c|}{ Similar/same reality } & \multicolumn{3}{|c|}{ Different reality } \\
\hline \multicolumn{2}{|c|}{ Similar/same segmentation } & \multirow{2}{*}{$\begin{array}{c}\text { Different } \\
\text { segmentation } \\
\text { Partial } \\
\text { equivalence }\end{array}$} & \multirow{2}{*}{$\begin{array}{c}\text { Lacking unit } \\
\text { Lack of } \\
\text { equivalence }\end{array}$} & \multirow{2}{*}{$\begin{array}{c}\begin{array}{c}\text { Non- } \\
\text { lexicalized } \\
\text { concepts }\end{array} \\
\text { Weak/lack of } \\
\text { equivalence }\end{array}$} & \multirow{2}{*}{$\begin{array}{c}\text { Different system } \\
\text { Weak/lack of } \\
\text { equivalence }\end{array}$} \\
\hline $\begin{array}{c}\text { Absolute } \\
\text { equivalence }\end{array}$ & $\begin{array}{c}\text { Working } \\
\text { equivalence }\end{array}$ & & & & \\
\hline Terminology & $\begin{array}{c}\text { International } \\
\text { vocabulary }\end{array}$ & $\begin{array}{l}\text { Major part of } \\
\text { the central } \\
\text { vocabulary }\end{array}$ & \multicolumn{3}{|c|}{ Culture-specific items } \\
\hline $\begin{array}{l}\text { Di sản thế giới } \\
\text { World heritage }\end{array}$ & $\begin{array}{c}\text { Vật tổ } \\
\text { Totem, Idol }\end{array}$ & $\begin{array}{c}\text { Miếu thò } \\
\text { Temple, Shrine }\end{array}$ & $\begin{array}{c}\text { Áo toi } \\
(-) \\
\text { palm-leaf } \\
\text { raincoat/palm- } \\
\text { leaf poncho }\end{array}$ & $\begin{array}{c}\text { Bánh trôi nưócc } \\
\text { (-) } \\
\text { Floating rice } \\
\text { cake/glutinous } \\
\text { rice ball }\end{array}$ & $\begin{array}{c}\text { Tục nối dây (Juê } \\
\text { nuê) } \\
\text { Custom of Juê } \\
\text { Nuê/sibling- } \\
\text { replaced } \\
\text { marriage }\end{array}$ \\
\hline
\end{tabular}

For example, if we have similar or same reality and similar segmentation, i.e., similar meaning components in both connotation and denotation, we can easily have absolute or working equivalents: $D i$ sản thế giới (a landmark/space in Viet Nam with cultural, historical values that is internationally of feudalism in Viet Nam. As for the third category, 61 ethnic items about names of people and nicknames faced us with no fewer challenges.

\subsection{Translation of culture-specific items in texts about cultural festivals from Vietnamese into English}

Based on the types of equivalence by Heltai [33] (2007) as analyzed in [22], we found out scenarios for the English equivalents of CSIs in texts about Vietnamese cultural festivals. As can be seen, there are 6 cases, depending on the similarities or differences in reality, as shown in Table 2. 
cultural relic in Vietnamese folklore, built to worship a certain local god, usually smaller in size than a pagoda and located in a quiet, sacred place in a village) $=$ Temple, Shrine. In these cases, we can apply the strategy of assimilation. These findings completely support the view that CSIs are contextually dependent, and the referential equivalence approach helps us to fully understand them and choose appropriate translation methods to deal with them.

In another respect, if we have a different reality, due to non-lexicalized concepts, different systems, or lacking units, we can employ strategies exoticization or explanation or combine two strategies, namely exoticization with explanation or assimilation with explanation to find out weak equivalence in the form of partial equivalent that is acceptable and understandable thanks to supporting explanation. For example, in the case of the CSI "áo toi," we have to use a strategy combining assimilation and explanation: This item refers to a piece of wearing made from palm leaves (usually used for thatch roofs in the countryside in Viet Nam); and during the national history, it has been used as a means to protect people, especially in North Viet Nam, from rain, heating sun in summer, and cold weather in winter. In terms of shape, it is somehow similar to a poncho in western countries. As a result, we just have weak equivalence or lack equivalence; then we decide to translate this item into palm-leaf raincoat if the context concerns the rainy season in the North of Viet Nam, or palm-leaf poncho as a way for foreigners to visualize its denotative meaning.

In the case of Bánh trôi nước, it is a traditional ballshaped cake, often used for worship offerings. Many people think that its name derives from the cooking process in which rice balls will float in the pot when the water is boiling. However, historically, this name refers to the image of hundreds of eggs in the tale of Descendants of the Fairy and the Dragon, which legendarily depicts the origin of the Vietnamese people. Thus, the equivalent "floating rice cake" using the strategy of exoticization (i.e., literal translation) is weak because it loses the cultural and historical values reflected in the cake's name. However, it is not easy to find out a name in English that fully depicts its root without further explanation.

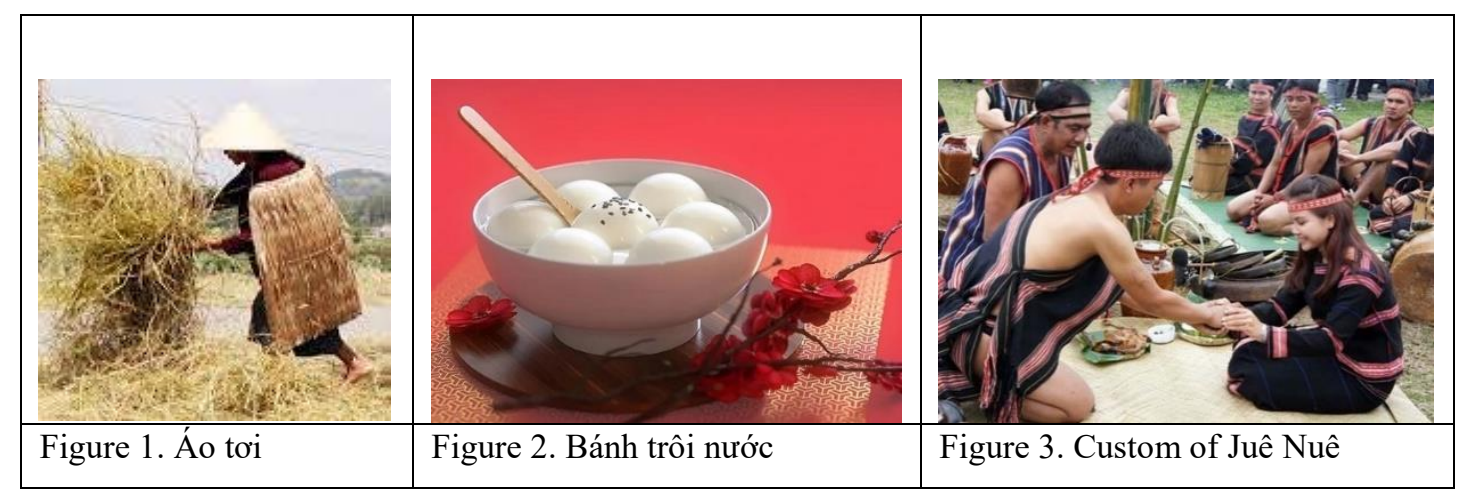

The final scenario is applied to those involving the different systems. The custom of Juê Nuê is a traditional marriage of the Ede, an ethnic minority in the Central Highlands of Viet Nam. This custom stipulates that when a husband dies, his wife has the right to demand that the husband's family replace the 
dead with his brother to be her new husband; similarly, when a wife dies, her husband is requested to marry her sister as long as she is still single. It seems to be impossible to find a similar custom in western societies, so an absolute or working equivalent is not found. In this case, we suggest two equivalents using the strategy exoticization and explanation, respectively.

The three scenarios in case of different reality give strong evidence for differences in the category of art and culture between Vietnamese and English as depicted by Hùng [34, p.125), "for a linguistic expression about deep cultural values of the native community, finding an absolute equivalent seems to be impossible."

To further illustrate how CSIs in the five categories can be translated into English, some more exemplary items are presented in Table 3 as follows:

Table 3. Some CSIs in Vietnamese and their equivalents in English

\begin{tabular}{|c|c|c|c|}
\hline Category & CSI in Vietnamese & Interpretation & Equivalence in English \\
\hline \multirow[t]{3}{*}{ Geographical } & bãi bồi ven sông & $\begin{array}{l}\text { It refers to a piece of land rising } \\
\text { along a river or in the middle of } \\
\text { large streams of water. }\end{array}$ & $\begin{array}{l}\text { coastal alluvial ground, } \\
\text { terra firma }\end{array}$ \\
\hline & gò & $\begin{array}{l}\text { It is a ground rising high in the } \\
\text { middle of flat land. }\end{array}$ & mound, hillock, knoll \\
\hline & nhà thờ (tổ) & $\begin{array}{l}\text { It is a space to worship the ancestors } \\
\text { of a clan or family. }\end{array}$ & $\begin{array}{l}\text { ancestral worship house, } \\
\text { house for ancestor veneration }\end{array}$ \\
\hline \multirow[t]{3}{*}{ Ethnographic } & chè & $\begin{array}{l}\text { It is a type of sweet soup cooked } \\
\text { with ingredients such as sugar or } \\
\text { honey, rice flour, beans, etc., used as } \\
\text { refreshment. }\end{array}$ & sweet dessert soup \\
\hline & cỗ báu ngọc & $\begin{array}{l}\text { It depicts a set or a tray of paper } \\
\text { models for precious stones used as } \\
\text { jewelry or decoration. }\end{array}$ & $\begin{array}{l}\text { joss paper offerings } \\
\text { tray of papercrafts for worship }\end{array}$ \\
\hline & khăn đóng & $\begin{array}{l}\text { It is a type of headscarves for men } \\
\text { in the old days, usually being black, } \\
\text { folded in circular pleats, and not } \\
\text { covering the head top. }\end{array}$ & $\begin{array}{l}\text { Vietnamese turban, } \\
\text { Vietnamese headscarf }\end{array}$ \\
\hline \multirow[t]{2}{*}{$\begin{array}{l}\text { Art and } \\
\text { culture }\end{array}$} & lễ cúng an vị & $\begin{array}{l}\text { It refers to a ceremony for placing a } \\
\text { new bowl of incense on the } \\
\text { ancestral altar in a new house. }\end{array}$ & $\begin{array}{l}\text { thurible/incensory/censer settling } \\
\text { ceremony or ritual, } \\
\text { settlement ceremony }\end{array}$ \\
\hline & hát Bả trạo & $\begin{array}{l}\text { It is a kind of folklore performance } \\
\text { that is ritualistic of the coastal } \\
\text { inhabitants in Central Viet Nam; } \\
\text { "bả" means "firmly grip," "trạo" }\end{array}$ & $\begin{array}{l}\text { Bả trạo singing and dancing; } \\
\text { Rowing boat singing and } \\
\text { dancing }\end{array}$ \\
\hline
\end{tabular}




\begin{tabular}{|c|c|c|c|}
\hline Category & CSI in Vietnamese & Interpretation & Equivalence in English \\
\hline & & $\begin{array}{l}\text { means "paddle"). It is held annually } \\
\text { on the occasion of the sacrifice of } \\
\text { the Whale (Cá Ông) or fishermen's } \\
\text { prayer. It describes the hard work of } \\
\text { fishermen in the middle of the sea } \\
\text { and praises the wealth of the sea as } \\
\text { well as the fishermen's solidarity } \\
\text { for a prosperous life. }\end{array}$ & \\
\hline & đua thuyền tứ linh & $\begin{array}{l}\text { It is the four supernatural creature } \\
\text { boat racing in which there are } 4 \\
\text { racing boats decorated with } \\
\text { symbolic shapes and bearing the } \\
\text { names of the animals regarded as } \\
\text { the four supernatural creatures } \\
\text { being dragon, unicorn, tortoise, } \\
\text { phoenix in the traditional } \\
\text { Vietnamese belief. }\end{array}$ & $\begin{array}{l}\text { race with boats in } \\
\text { the shape of the four sacred } \\
\text { animals, namely dragon, } \\
\text { unicorn, tortoise, and phoenix, } \\
\text { the four supernatural creature } \\
\text { boat racing }\end{array}$ \\
\hline \multirow[t]{3}{*}{ Ethnic } & Cá Ông & $\begin{array}{l}\text { It is about a god being a gray back } \\
\text { whale which is worshiped as the sea } \\
\text { god by fishermen. In their belief, the } \\
\text { Whale God is always willing to help } \\
\text { and bless them on their sea } \\
\text { journeys. }\end{array}$ & $\begin{array}{l}\text { the (Holy) Whale, } \\
\text { Whale God }\end{array}$ \\
\hline & Bà Mẹ Xứ Sở & $\begin{array}{l}\text { This refers to the mother of the land, } \\
\text { a name that the Vietnamese gave the } \\
\text { goddess Po yan Ynư Nagar of the } \\
\text { Cham people. "Po" means "divine," } \\
\text { and "yan" means "goddess." }\end{array}$ & $\begin{array}{l}\text { Poh Yang Ina Nagar, } \\
\text { Po Ino Nogar, } \\
\text { Mother of Land }\end{array}$ \\
\hline & Nàng Hai & $\begin{array}{l}\text { This is about a holy lady (literally } \\
\text { called Miss Hai), known as Mother } \\
\text { of Moon, who is the chief goddess } \\
\text { in a festival of the Tay ethnic } \\
\text { minority in Cao Bằng, a province in } \\
\text { North Viet Nam. According to their } \\
\text { folk belief, on the moon live Mother } \\
\text { of Moon and twelve fairies who are } \\
\text { her daughters. These ladies take } \\
\text { care of their crops on earth. }\end{array}$ & $\begin{array}{l}\text { Lady Hai } \\
\text { Moon Goddess, } \\
\text { Mother of Moon }\end{array}$ \\
\hline $\begin{array}{l}\text { Socio- } \\
\text { political }\end{array}$ & các bậc tiền nhân & $\begin{array}{l}\text { They are persons in the previous life } \\
\text { who are related to the local people; } \\
\text { persons of past generations who } \\
\text { share some similarities with the } \\
\text { present generation. }\end{array}$ & $\begin{array}{l}\text { predecessors, } \\
\text { ancestors, } \\
\text { the First Men (adapted from } \\
\text { Games of Thrones) }\end{array}$ \\
\hline
\end{tabular}




\begin{tabular}{|c|c|c|c|}
\hline Category & CSI in Vietnamese & Interpretation & Equivalence in English \\
\hline & cai đội & $\begin{array}{l}\text { It refers to a martial officer or a } \\
\text { captain in the Nguyễn Dynasty. He } \\
\text { managed a troop of about } 200-500 \\
\text { soldiers in localities. His rank is } \\
\text { similar to that of a captain in } \\
\text { western countries. }\end{array}$ & $\begin{array}{l}\text { master, } \\
\text { commander, } \\
\text { captain }\end{array}$ \\
\hline & $\begin{array}{l}\text { Uy Minh Vương } \\
\text { Lý Nhật Quang }\end{array}$ & $\begin{array}{l}\text { Lý Nhật Quang was a prince and } \\
\text { mandarin of the Lý dynasty in old } \\
\text { Vietnamese history. He was } \\
\text { honored as a saint by the people of } \\
\text { Nghệ Tĩnh, the biggest province in } \\
\text { the Central North. He was } \\
\text { appointed as the head of Nghẹ An } \\
\text { region (similar to a prefect of a local } \\
\text { government in a district in Western } \\
\text { countries) with the title Uy Minh } \\
\text { Vương Lý Nhật Quang, which } \\
\text { means he was a powerful and } \\
\text { intellectual governor. }\end{array}$ & $\begin{array}{l}\text { Prince Lý Nhật Quang, } \\
\text { Duke Uy Minh, } \\
\text { Prefect Lý Nhật Quang, } \\
\text { Great Governor Lý Nhật Quang }\end{array}$ \\
\hline
\end{tabular}

Take, for example, the CSI "che”" in the ethnographic category is a common dish for ceremonies in Vietnamese cultural festivals and also serves as a dessert. In western countries, common desserts are cakes rather than soup. Thus, we have a similar reality but different segmentation, then we decide to use the strategy assimilation with explanation and choose a partial English equivalent "sweet dessert soup" in which the major part of the central vocabulary is soup because this Vietnamese dessert is somehow similar to soup in western countries.

\section{CONCLUSIONS AND IMPLICATIONS}

The paper collected 300 texts about 100 popular cultural festivals in Viet Nam from reliable printed or online sources. Then 611 culture-specific items in the nominal form were identified and interpreted based on the widely-used types of translation equivalents and methods. The research findings signified that the research group was successful in answering the two
Another explanation is for the CSI "Nàng Hai" in the ethnic category. Certainly, we cannot find this Goddess in western countries. That means we have different reality and this item refers to a nonlexicalized concept, then we decide to use the strategy exoticization for the case of the equivalent "Lady Hai"; however, we can also use the strategy assimilation for the case of the working equivalent "Moon Goddess" or "Mother of Moon" based on our interpretation.

research questions by identifying appropriate equivalence scenarios and applying appropriate strategies for translating CSIs in Vietnamese cultural festival texts.

However, several problematic issues arise in the translation process because cultural patterns of the Vietnamese society are very different from those in western ones where English is used. It makes sense 
because once cultural features are particular to one society, translating them could be a painful task [22]. It reveals that translating the CSIs found in texts about Vietnamese cultural festivals is a tough process and requires a lot of research and effort.

The research results have significant implications for translation theory and practice. In details:

(1) The selection of translation strategies should be carefully done with the thorough interpretation of both their denotative and connotative meanings before any decision of translation equivalents is made. In fact, the translator may find more than one choice to decide an equivalent of a CSI based on the three groups of strategies by Kwieciński [23], namely exoticization, explanation, and assimilation. That is a reason why many of the CSIs in Vietnamese were given more than one equivalent in English, depending on their particular contexts. These variations are a particular factor in the translation of CSIs [35].

(2) The research findings are a useful reference for translation education as an authentic practice in class. Concretely, translation-majored students should be encouraged to brainstorm and learn how to use appropriate strategies in their translation process, which helps improve their translation skills and enhance their creativity. In addition, this research is a good start for the corpus construction of bilingual dictionaries.

Due to the limited scale of the research, the subject is only noun phrases grouped into five categories based on Vlahov \& Florin [16] (1980). Thus, many other CSIs in the form of the verb and adjective phrases are beyond this research. Further research on various linguistic forms of CSIs is recommended, then a complete Vietnamese-English dictionary of CSIs in cultural festivals can come into life.

All in all, our research serves as a starting point to build up a Vietnamese-English lexical corpus to support lecturers and students in Viet Nam's universities who are interested in tourism; and it is suggested to be used as a reliable reference source of communication about cultural festivals in particular and tourism in general.

\section{AUTHORS' CONTRIBUTION}

The research group consists of five members from the University of Social Sciences \& Humanities, Viet Nam National University Ho Chi Minh City. They are: Nguyễn Thị Như Ngọc, who is currently Vice-dean of the Faculty of English Linguistics and Literature (EF) and Chair of the Department of Translation and Interpreting, and whose areas of interest are Translation Studies, Comparative Linguistics, and Intercultural Communication; Văn Thị Nhã Trúc, who is currently a lecturer of the Department of American and British Culture and Literature at the EF, and whose areas of interest are Business Culture, English literature, and Intercultural Communication; Nguyễn Anh Quân, who is currently a lecturer and holds a position of Director of the Center for International Education, and whose areas of interest are TESOL, ICT in language teaching, and internationalization at higher education; Lê Thị Ngọc Ánh, who is currently a lecturer of the Department of Translation and Interpreting at the EF, and whose areas of interest are translation, applied linguistics, language teaching and education; and Trần Cao Bội Ngọc, who is currently a lecturer of the Department of Australian Studies, Faculty of Oriental Studies, and whose areas of interest are anthropology, cultural studies, and English language teaching.

The contribution of each author is as follows:

Nguyễn Thị Như Ngọc analyzed the research data and wrote the paper. 
Văn Thị Nhã Trúc collected the data and proofread the paper.

Nguyễn Anh Quân collected the data and proofread the paper.

Lê Thị Ngọc Ánh and Trần Cao Bội Ngọc collected the data.

\section{ACKNOWLEDGMENTS}

This paper is a product of a university-level research project. Starting in early 2021, the project is on course and is supposed to be completed in March 2022. We would like to express our great thanks to the USSH, VNUHCM for approving our proposal via Announcement No. 787/TB-XHNV-ĐN\&QLKH, dated December 16, 2020.

\section{REFERENCES}

[1] N. Hà, Du lịch tâm linh và những vấn đề cần quan tâm, Tạp chí Công tác Tôn giáo số, (7), 2019. DOI: http://btgcp.gov.vn/tin-bai-nghiencuu-va-trao-doi-y-kien-cua-docgia/Du_li_ch_tam_linh_va_nhu_ng_va_n_de _ca_n_quan_tam-postBmZEwxqW.html

[2] A. Falassi, Festival: Definition and morphology, Time out of Time: Essays on the Festival, University of New Mexico Press, Albuquerque, 1987, p.1. Available: https://www.brown.edu/Departments/Joukowsky_Institute/courses/citya ndfestival09/files/9722047.PDF

[3] C. X. Zhang, L. H. N. Fong, S. Li, \& T. P. Ly, National identity and cultural festivals in postcolonial destinations, Tourism Management (73), 2019, pp. 94-104. DOI:10.1016/j.tourman.2019.01.013

[4] https://www.lexico.com/definition/cultural_festi val

[5] https://www.eunwto.org/doi/pdf/10.18111/9789284416738
[6] D. Đ. Minh, Du lịch tâm linh tại Việt Nam: những vấn đề lý luận và thực tiễn, Science \& Teachnology Development Journal, Vol. 19 (X5), VNUHCM, pp.37-47.

[7] http://www.vietnamtourism.com/index.php/about/items/2391

[8] https://vietnamtourism.gov.vn/esrt/VTOS2015 Travel_Tour_Operations_EN.pdf

[9] Viet Nam's MOET, Vietnamese Literature Grade 10 - Vol.2, Viet Nam Education Publishing House, 2010.

[10] N. T. Hùng, Dịch thuật: Từ lý thuyết đến thực hành, HCMC: Văn hóa Sài Gòn Publisher, 2005.

[11] J. C. Catford, A Linguistic Theory of Translation, London: Oxford University Press, 1965.

[12] E. A. Nida, C. R. Taber, The Theory and Practice of Translation, With Special Reference to Bible Translating, Leiden: Brill, 1969.

[13] M. L. Larson, Meaning Based Translation, A Guide to Cross-language Equivalence. Lanham: University Press of America, 1984.

[14] P. Newmark, A Textbook of Translation, London: Prentice Hall International Ltd., 1988.

[15] J. F. Aixelá, Culture-specific items in Translation, in Román Álvarez and Carmen A. Vidal (Eds.), Translation, Power, Subversion. Clevedon: Multilingual Matters, 1996, pp. 5278.

[16] S. Vlahov \& S. Florin, Neperevodimoje v perevode, Moskva: Meždunarodnyje otnošenija, 1980.

[17] D. Blažytė \& V. Liubinienè, Culture-Specific Items (CSI) and their Translation Strategies in 
Martin Lindstrom's Brand Sense, Research Journal Studies about Languages, No. 29 (C) Kaunas University of Technology, 2016, pp. 4257.

DOI: http://dx.doi.org/10.5755/j01.sal.0.29.15129

[18] A. Pym \& H. Turk, Translatability, in M. Baker (ed). Routledge Encyclopedia of Translation Studies, London and New York: Routledge, 2019, pp. 273-277.

[19] H. Friedrich, On the Art of Translation, translated by R. Schulte \& J. Biguenet, in R. Schulte \& J. Biguenet (Eds.), Theories of Translation: An Anthology of Essays from Dryden to Derrida, Chicago: University of Chicago Press, 1992, pp. 11-16.

[20] T. Hermans, Translatability, in M. Baker \& M. G. Saldanha (Eds.), Routledge Encyclopedia of Translation Studies ( $2^{\text {nd }}$ ed.). London and New York: Routledge, 2009, pp. 300-303.

[21] M. Baker, In other words. London: Routledge, 1992.

[22] E. Terestyényi, Translating Culture-specific items in Tourism Brochures, SKASE Journal of Translation and Interpretation [online], vol. 5, no. 2, 2011, pp. 11-21. Available: http://www.skase.sk/Volumes/JTI06/pdf_doc/02 .pdf

[23] P. Kwieciński, Disturbing strangeness: foreignisation and domestication in translation procedures in the context of cultural asymmetry, Torun: Wydawnictwo Edytor, 2001.

[24] C. Schäffner \& U. Wiesemann, Annotated texts for translation: English-German: functionalist approaches illustrated, Clevedon: Multilingual
Matters, 2001.

[25] H. V. Dastjerdi \& S. D. Abdolmaleki, A Study of Translation Problems of Tourism Industry Guidebooks: An Error Analysis Perspective, International Journal of Foreign Language Teaching and Research, Vol. 1, Issue 1, 2013, pp. 71-82. Available: http://jfl.iaun.ac.ir/article_550500.html

[26] O. Skibitska, The Translation of Tourism Websites, in FLLT Conference Proceedings by LITU, Issue 2. No.1, 2013, pp.735-740.

[27] S. Yifeng \& T. Fang, A Parallel Corpus-based Investigation of Vocabulary Features of Tourism Translations, International Journal of Linguistics and Communication, vol. 2 (3), 2014, pp. 01-22. DOI: 10.15640/ijlc.v2n3a1

[28] E. Bagheridoust \& Z. M. Mahabad, Translation of culture-specific items: a case study of Persian architecture terminology, International Journal of Applied Linguistics and English Literature, vol. 6 (2), 2017, pp. 46-55. Available: https://www.journals.aiac.org.au/index.php/IJA LEL/article/view/2887.

[29] L. T. Hà, Đối chiếu thuật ngũ du lịch Anh - Việt, Doctoral thesis in Vietnam Academy of Social Sciences, 2015.

[30] N. T. M. Tâm, N. D. Hồng, T. T. Long, Khảo sát thực trạng sử dụng tiếng Anh trong các biển hướng dẫn du lịch tại một số điểm du lịch ở miền Bắc Việt Nam, VNJ Journal of Foreign Studies, vol. 33 (2), 2017, pp. 90-104. Available: https://js.vnu.edu.vn/FS/article/view/4144.

[31] P. L. Oanh \& N. Hoàng, Hướng dẫn quản lý, tổ chức lễ hội truyền thống ở cơ sở, Ha Noi: 
National Political Publishing House, 2015.

[32] https://docs.rws.com/binary/796827/807059/sdl -multiterm-2021/sdl-multiterm-extract-toolsuser-guide?

[33] P. Heltai, Ekvivalencia és kulturálisan kötött kifejezések a fordításban. In Heltai Nyelvi Modernizáció: Szaknyelv, fordítás, terminológia. Manye: Pécs- Gödöllő, 2007, pp. 643-653.

[34] B. M. Hùng, Ngôn ngữ học Đối chiếu, Viet Nam Education Publishing House, 2008.

[35] J. Munday, Introducing Translation Studies Theories and Applications, New York: Routledge, 2001. 